\title{
Peel resistance and stiffness of woven fabric with fusible interlinings
}

\section{Rezistența la sfâșiere și rigiditatea țesăturilor cu căptușeală fuzibilă}

Căptușeala este un strat de țesătură plasat între țesături pentru a forma și a spori rigiditatea îmbrăcămintei. Căptușeala fuzibilă poate fi atașată la țesătură la o anumită temperatură, timp și presiune. Acești parametri sunt foarte importanți pentru rezistența la uzură și rigiditatea țesăturii cu căptușeală fuzibilă.

În acest studiu, țesătura de bază confecționată din bumbac și trei căptușeli fuzibile diferite (legături pânză, diagonal și căptușeală nețesută fuzibilă) au fost alese ca probe experimentale. Diferite temperaturi de topire între $130^{\circ} \mathrm{C} s ̦ i 170^{\circ} \mathrm{C}$ și durate diferite de topire (5-10 și $15 \mathrm{sec})$ au fost selectate pentru topirea căptușelii pe țesătură. Scopul acestui studiu este de a investiga efectul temperaturii de topire și a timpului asupra rezistenței la sfâșiere și a rigidității țesăturii cu căptușeală fuzibilă.

Rezultatele au arătat că rigiditatea țesăturii cu căptușeală fuzibilă din bumbac cu legătură pânză a crescut odată cu creșterea temperaturii de topire și a timpului de topire. Rezultatele au arătat că rigiditatea țesăturii cu căptușeală fuzibilă din poliester cu legătură diagonal a crescut odată cu creșterea temperaturii de topire și a scăzut odată cu timpul de topire. Rezultatele au arătat că rigiditatea țesăturii cu căptușeală fuzibilă din nețesute din poliamidă a crescut odată cu creșterea temperaturii de topire până la $140^{\circ} \mathrm{C}$ și cu creșterea timpului de topire până la 10 sec. Rezultatele au arătat că rezistența la sfâșiere dintre căptușeala fuzibilă din bumbac cu legătură pânză și poliesterul cu legătură diagonal și țesătura de bază au crescut odată cu creșterea temperaturii și a timpului de topire.

Cuvinte-cheie: căptușeală fuzibilă, lungime de îndoire, rezistență la sfâșiere, rigiditate

\section{Peel resistance and stiffness of woven fabric with fusible interlinings}

Interlining is a layer of fabric placed between the garment fabrics to form and enhance the stiffness of the garment. The fusible interlining can be bonded to the fabric at a specific temperature, time and pressure. These parameters are very important for the peel resistance and stiffness of the fabric with fusible interlining.

In this study, cotton woven face fabric and three different fusible interlinings(plain, twill and nonwoven fusible interlining)were chosen as experimental samples. Different fusing temperatures between $130^{\circ} \mathrm{C}$ and $170^{\circ} \mathrm{C}$ and different fusing times (5-10 and $15 \mathrm{sec}$ ) selected for fusing of the interlinings to the fabric. The purpose of this study is to investigate the effect of fusing temperature and time on peel resistance and stiffness of fabric with fusible interlinings. Results indicated that the stiffness of the fabric withcotton plain fusible interlining increased with increase fusing temperature and fusing time. Results indicated that the stiffness of the fabric withpolyester twill fusible interlining increased with increase fusing temperature and decrease fusing time. Results indicated that the stiffness of the fabric with polyamide nonwoven fusible interlining increased with increase fusing temperature until $140^{\circ} \mathrm{C}$ and increase fusing time until $10 \mathrm{sec}$. Results indicated that the peel resistance between the cotton plain and polyester twill fusible interlining andface fabric increased with increase fusing temperature and fusing time.

Keywords: fusible interlining, bending length, flexural rigidity, peel resistance, stiffness

\section{INTRODUCTION}

Interlining is a kind of accessory used between the two layers of fabric in a garment. A fusible interlining is thin layer made from woven, knitted or nonwoven material bonded mechanically or thermally which fused with fabric can give durability, reinforcement, and can also stabilize and makes easy sewing. The fusible interlining can be bonded to the fabric at a specific temperature, time and pressure. In order to improve the appearance and stability of the garment, fusible interlining is often used with the fabric of the garment [1].

Interlinings play an important role in shaping the details areas of garments such as the collars, front of coats, cuffs, lapels and pocket flaps. They also, strengthen some of the clothes areas subject to extra wearing stress, such as patch pockets, necklines, facings, waistbands, button holes and plackets [2]. There are mainly two types of interlining; fusible interlining and non-fusible interlining. The interlining which is used between two layers of fabrics directly by sewing without heat and pressure is called nonfuse interlining. This type of interlining is also called sewn interlining or non-fusible interlining. For the preparation of sewn interlining a piece of fabric is treated with starch and allowed to dry and finally sewn with main fabric. It is most used interlining.

The interlining which can be fixed with the garments components by applying heat and pressure for specific period of time is called fusible interlining. Fusible interlining is used for all kinds of garment. During fusing, recommended temperature needed 
THE STRUCTURAL PARAMETERS OF FUSIBLE INTERLININGS USED

\begin{tabular}{|c|c|c|c|c|}
\hline $\begin{array}{c}\text { Fusible } \\
\text { interlining code }\end{array}$ & Weave type & $\begin{array}{c}\text { Weight } \\
\left(\mathbf{g} / \mathbf{m}^{2}\right)\end{array}$ & $\begin{array}{c}\text { Weight of fabric fused } \\
\text { with interlining }\left(\mathbf{g} / \mathbf{m}^{2}\right)\end{array}$ & $\begin{array}{c}\text { Adhesive type on fusible } \\
\text { interlining }\end{array}$ \\
\hline 11 & $\begin{array}{c}\text { Plai } \\
(\% 80 \text { Polyester } / \\
\% 20 \text { Cotton })\end{array}$ & 114 & 209 & HD Polietilen \\
\hline 12 & $\begin{array}{c}\text { Twill } 2 / 2 \\
(\% 100 \text { Polyester })\end{array}$ & 60 & 155 & Poliamide \\
\hline 13 & $\begin{array}{c}\text { Nonwoven } \\
(\% 100 \text { Polyamide })\end{array}$ & 35 & 130 & Multi component poliamide \\
\hline
\end{tabular}

$110-170^{\circ} \mathrm{C}$ where fusing time needed $2-20 \mathrm{sec}$ and pressure depends on fusing technique [3].

Appropriate working conditions are required for the proper bonding of the fusible interlining to the fabric. A perfectly balanced combination of temperature, pressure and time ensures excellent adhesion. Therefore, the temperature, pressure and time should be often checked periodically every day and well documented. These variables have an important influence on the peel resistance and the bending properties of the fabrics fused with interlinings [4].

The aim of a peel resistance test is to determine the adhesive strength of the interlining. This adhesive strength may be referred to as the "stickiness" of a material as it is a measure of the samples resistance to separation from one another after the adhesive has been applied. Peel resistance may then be used to determine if the adhesive bond is strong enough or too strong for the application and whether a different adhesive or bonding process is needed.

Although interlining is an invisible interior part of a garment, the interlining construction and the fusion process of interlining and face fabric affect sewability, appearance and mechanical properties of the garment [5-6]. Fusible interlinings are the most popular in clothing industry, making the shirt fabric fuller and stiffer in order to achieve the good silhouette and performance [7].

Fabric bending behaviour is generally characterized by its bending or flexural rigidity. Bending behaviour is one of the most important properties used to define the stiffness of fabric and fusible interlinings. To evaluate the stiffness of a fabric, bending length and flexural rigidity must be tested [8].

In this study, the effects of different fusing temperature and fusing time on peel resistance and stiffness of woven fabrics fused with three different fusible interlinings were examined.

\section{MATERIALS AND METHODS}

\section{Materials}

In this study, $95 \mathrm{~g} / \mathrm{m}^{2}$ plain woven face fabric containing $80 \%$ of polyester $-20 \%$ cotton and cotton plain woven, polyester twill woven and polyamid nonwoven fusible interlinings have been used. The fusing was performed by using interlining press machine (Konsan). Both fabric and fusible interlinings were cut and fused in warp directions.
Face fabric was fused with three different fusible interlinings with different fusing temperatures and times. The press machine pressure was $6 \mathrm{~kg} / \mathrm{cm}^{2}$. All the measurements were performed after conditioning of the fused panels for 24 hours under the standard atmospheric conditions: $20^{\circ} \mathrm{C} \pm 2{ }^{\circ} \mathrm{C}$ and relative humidity $65 \% \pm 5 \%$.

The structural properties of the fusible interlinings used are shown in table 1. The fusing conditions of fabric samples fused with interlining used in this study are shown in table 2 .

Table 2

\begin{tabular}{|c|c|c|c|}
\hline \multicolumn{4}{|c|}{$\begin{array}{l}\text { FUSING CONDITIONS OF FABRIC SAI } \\
\text { WITH INTERLINING }\end{array}$} \\
\hline $\begin{array}{c}\text { Fusible } \\
\text { interlining } \\
\text { code }\end{array}$ & $\begin{array}{c}\text { Code } \\
\text { of fabrics } \\
\text { fused with } \\
\text { interlining }\end{array}$ & $\begin{array}{c}\text { Fusing } \\
\text { temperature } \\
\left({ }^{\circ} \mathrm{C}\right)\end{array}$ & $\begin{array}{c}\text { Fusing } \\
\text { time } \\
\text { (sec) }\end{array}$ \\
\hline \multirow{8}{*}{11} & $11 \mathrm{a}$ & 150 & 10 \\
\hline & $11 \mathrm{~b}$ & 155 & 10 \\
\hline & $11 \mathrm{c}$ & 160 & 10 \\
\hline & $11 \mathrm{~d}$ & 165 & 10 \\
\hline & $11 \mathrm{e}$ & 170 & 10 \\
\hline & $11 \mathrm{f}$ & 160 & 5 \\
\hline & $11 \mathrm{~g}$ & 160 & 10 \\
\hline & $11 \mathrm{~h}$ & 160 & 15 \\
\hline \multirow{8}{*}{12} & $12 \mathrm{a}$ & 130 & 10 \\
\hline & $12 \mathrm{~b}$ & 135 & 10 \\
\hline & $12 \mathrm{c}$ & 140 & 10 \\
\hline & $12 d$ & 145 & 10 \\
\hline & $12 \mathrm{e}$ & 150 & 10 \\
\hline & $12 \mathrm{f}$ & 140 & 5 \\
\hline & $12 \mathrm{~g}$ & 140 & 10 \\
\hline & $12 \mathrm{~h}$ & 140 & 15 \\
\hline \multirow{8}{*}{13} & $13 \mathrm{a}$ & 130 & 10 \\
\hline & $13 b$ & 135 & 10 \\
\hline & $13 \mathrm{c}$ & 140 & 10 \\
\hline & $13 d$ & 145 & 10 \\
\hline & $13 \mathrm{e}$ & 150 & 10 \\
\hline & $13 \mathrm{f}$ & 140 & 5 \\
\hline & $13 \mathrm{~g}$ & 140 & 10 \\
\hline & $13 \mathrm{~h}$ & 140 & 15 \\
\hline
\end{tabular}




\section{Methods}

Different fused temperatures and different fused times selected and 24 fabric samples with fusible interlinings with different properties were observed. Weave types and adhesive types of fusible interlinings were different so that different fused temperatures and times were chosen on the recommendations of the interlining manufacturer companies.

To investigate the stiffness of a fabric, bending length and flexural rigidity must be obtained. The test to determine the "Bending of fabric" was carried out according to ASTM 1388-64 with using a stiffness tester [10]. Equations (1), (2) and (3) were used to calculate the stiffness of fabrics for each fabric strip.

$$
c=0 / 2
$$

$c$ is bending length;

$\mathrm{O}$ - the length of overhang, $\mathrm{cm}$.

$$
G=W(0 / 2)^{3}=W \times c^{3}
$$

$G$ is flexural rigidity, $\mathrm{mgcm}$;

$W$ - weigth per unit area, $\mathrm{mg} / \mathrm{cm}^{2}$.

$$
G_{o}=\left(G_{w} G_{f}\right)^{1 / 2}
$$

$G_{O}$ is overall flexural rigidity;

$G_{w}$ - warp flexural rigidity;

$G_{f}$ - weft flexural rigidity.

Four fabric samples were prepared in the warp direction from each fabric to evaluate the bending length. Peel resistance was evaluated between the fusible interlining and the face fabric after fusing. It was calculated according ASTM D 1876 and BS EN ISO 13934-1 standards with Titan universal testing machine [11-12]. Three fabric samples were prepared from each fabric to evaluate peel resistance.

\section{RESULTS AND DISCUSSION}

A perfect working fusing press and appropriate conditions are needed to achieve good results for fused interlinings to the fabrics. Only an exact balanced combination of temperature, pressure and time can guarantee an excellent adhesion. Therefore, the temperature, pressure and dwell time should be often checked periodically every day and well documented [9].

In this study, the effects of different fusing temperature and fusing time on peel resistance and stiffness of cotton fabrics fused with three different fusible interlinings were examined. To investigate the stiffness of fused fabrics, bending length and flexural rigidity were examined. Bending properties of face fabric and bending properties and peel resistance of fused fabric samples were shown in tables 3-4.

\section{The results of bending length and flexural rigidity}

To investigate the stiffness of a fabric, bending length and flexural rigidity must be obtained. Results indicated that the bending length and flexural rigidity of the fabric with cotton plain fusible interlining increased with increase fusing temperature and fusing time.

\begin{tabular}{|c|c|c|c|c|c|}
\hline \multicolumn{4}{|c}{ Table 3} \\
\hline \multirow{2}{*}{$\begin{array}{c}\text { Weave } \\
\text { type }\end{array}$} & $\begin{array}{c}\text { Bending length } \\
\text { (cm) }\end{array}$ & \multicolumn{2}{c|}{$\begin{array}{c}\text { Flexural } \\
\text { rigidity (mg cm) }\end{array}$} & $\begin{array}{c}\text { Overall } \\
\text { rigidity } \\
\text { (mg cm) }\end{array}$ \\
\cline { 2 - 5 } & Warp & Weft & Warp & Weft & 52.85 \\
\hline Plain & 2 & 1.57 & 76 & 36.76 & 56 \\
\hline
\end{tabular}

Low value of bending length means low stiffness and hence better drape ability. However, a high value of bending length indicates high stiffness or poor drape ability. As the temperature increased, the interlinings fused stronger to the fabric and hence stiffness of the fused fabric increased. The highest bending length and flexural rigidity for cotton fusible interlinings was at $160^{\circ} \mathrm{C}$ fusing temperature as shown in figures $1-2$.

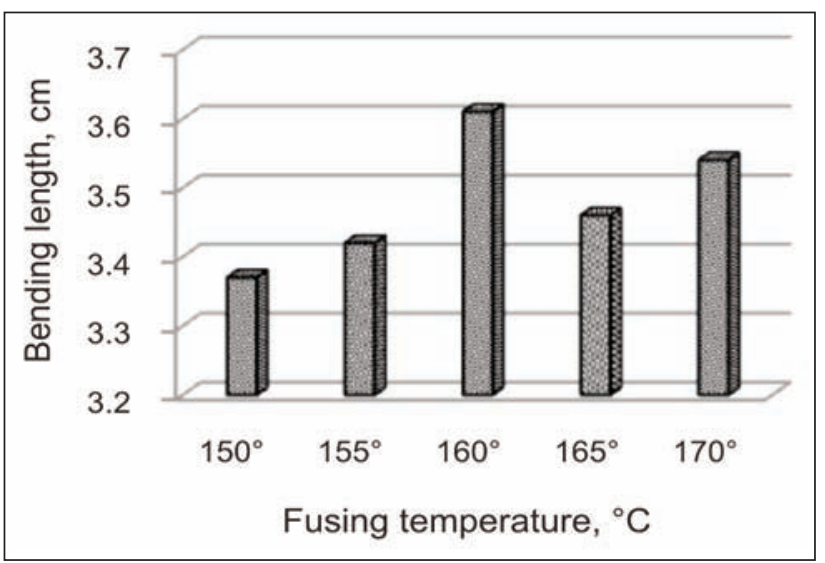

Fig. 1. Bending length of fabric with cotton plain fusible interlining at different fusing temperature

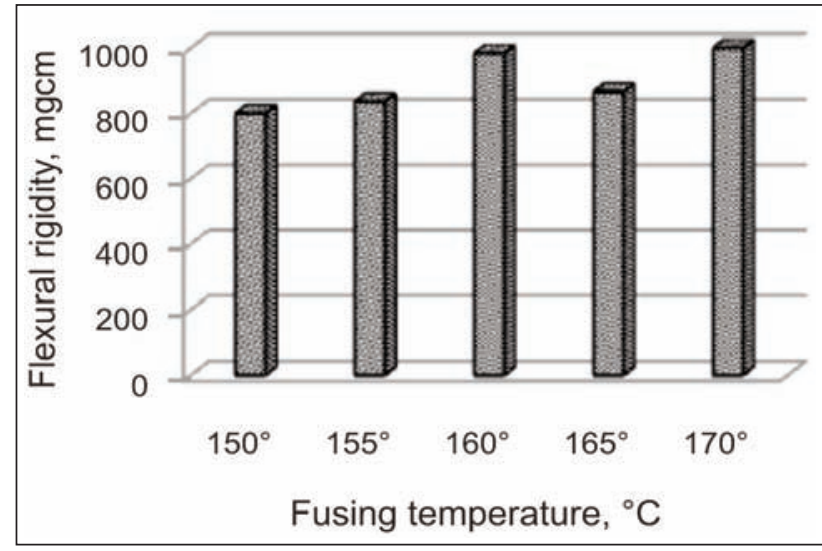

Fig. 2. Flexural rigidity of fabric with cotton plain fusible interlining at different fusing temperature

Interlining fusing time is also important for stiffness of fused fabric. The highest bending length and flexural rigidity for cotton fusible interlinings was at $15 \mathrm{sec}$ fusing time and $160^{\circ} \mathrm{C}$ fusing temperature as shown in figures 3-4.

Results indicated that the bending length and flexural rigidity of the fabric with polyester fusible interlining increased with increase fusing temperature. The highest bending length and flexural rigidity for 


\begin{tabular}{|c|c|c|c|c|c|c|c|}
\hline \multicolumn{8}{|c|}{ BENDING PROPERTIES AND PEEL RESISTANCE RESULTS OF FUSED FABRICS SAMPLE } \\
\hline \multirow{2}{*}{$\begin{array}{c}\text { Fused } \\
\text { interlining } \\
\text { code }\end{array}$} & \multirow{2}{*}{$\begin{array}{l}\text { Code of fabrics } \\
\text { fused with } \\
\text { interlining }\end{array}$} & \multicolumn{2}{|c|}{$\begin{array}{l}\text { Bending length } \\
(\mathrm{cm})\end{array}$} & \multicolumn{2}{|c|}{$\begin{array}{l}\text { Warp flexural rigidity } \\
(\mathrm{mg} \mathrm{cm})\end{array}$} & \multicolumn{2}{|c|}{$\begin{array}{l}\text { Peel resistance } \\
(\mathrm{N})\end{array}$} \\
\hline & & & $\% \mathrm{CV}$ & & $\% \mathrm{CV}$ & & $\% \mathrm{CV}$ \\
\hline \multirow{8}{*}{11} & $\mathrm{I1a}$ & 3.37 & 1.57 & 804.23 & 4.70 & 8.46 & 30.61 \\
\hline & I1b & 3.42 & 1.69 & 836.59 & 5.20 & 10.2 & 23.03 \\
\hline & I1c & 3.61 & 1.80 & 990.10 & 5.29 & 13.9 & 23.47 \\
\hline & I1d & 3.46 & 3.03 & 882.40 & 8.56 & 16.9 & 17.39 \\
\hline & I1e & 3.63 & 1.10 & 999.97 & 3.37 & 14.2 & 21.40 \\
\hline & I1f & 3.54 & 1.55 & 933.58 & 4.65 & 6.6 & 14.17 \\
\hline & $\mathrm{I1g}$ & 3.61 & 1.80 & 990.10 & 5.29 & 13.9 & 23.47 \\
\hline & I1h & 3.62 & 2.26 & 996.71 & 6.85 & 10.2 & 12.28 \\
\hline \multirow{8}{*}{12} & $12 a$ & 2.94 & 1.66 & 396.15 & 4.99 & 24.8 & 43 \\
\hline & $12 \mathrm{~b}$ & 2.92 & 2.02 & 386.26 & 6.16 & 33.5 & 11.88 \\
\hline & I2c & 2.95 & 0.57 & 404.19 & 1.72 & 32.6 & 1.99 \\
\hline & $12 d$ & 2.97 & 1.75 & 406.07 & 5.22 & 34.9 & 8.96 \\
\hline & $12 \mathrm{e}$ & 3.07 & 1.98 & 451.20 & 5.95 & 37.3 & 3.75 \\
\hline & $12 f$ & 3.06 & 0.16 & 445.20 & 0.48 & 17.7 & 38.52 \\
\hline & $\mathrm{I} 2 \mathrm{~g}$ & 2.95 & 0.57 & 404.19 & 1.72 & 32.6 & 2.19 \\
\hline & $\mathrm{I} 2 \mathrm{~h}$ & 2.95 & 0.88 & 400.01 & 2.67 & 29.7 & 14.98 \\
\hline \multirow{8}{*}{13} & $13 a$ & 2.16 & 1.57 & 131.99 & 4.69 & \multirow{8}{*}{\multicolumn{2}{|c|}{$\begin{array}{l}\text { Interlining not peelec } \\
\text { from fabric }\end{array}$}} \\
\hline & $13 \mathrm{~b}$ & 2.24 & 0.66 & 146.61 & 1.99 & & \\
\hline & I3c & 2.28 & 0.87 & 154.61 & 2.71 & & \\
\hline & I3d & 2.26 & 1.23 & 151.61 & 3.83 & & \\
\hline & $13 e$ & 2.23 & 1.56 & 144.24 & 4.72 & & \\
\hline & $I 3 f$ & 2.21 & 2.98 & 140.60 & 8.99 & & \\
\hline & $13 g$ & 2.28 & 0.87 & 154.61 & 2.71 & & \\
\hline & I3h & 2.18 & 1.95 & 135.64 & 3.26 & & \\
\hline
\end{tabular}

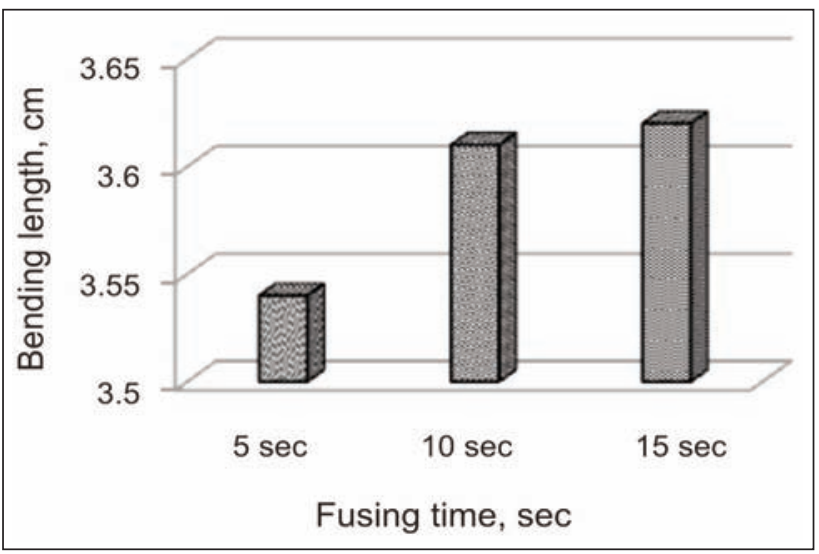

Fig. 3. Bending length of fabric with cotton plain fusible interlining at different fusing time at $160^{\circ} \mathrm{C}$

polyester fusible interlinings was at $150^{\circ} \mathrm{C}$ fusing temperature as shown in figures 5-6.

The highest bending length and flexural rigidity for polyester fusible interlinings was at $5 \mathrm{sec}$ fusing time and $140^{\circ} \mathrm{C}$ fusing temperature as shown in figures 7-8.

High quality nonwoven interlinings are made from $\% 100$ polyamide products with ultra fine coating to heavier blends. These are thermally or chemically bonded and used depending on applications.

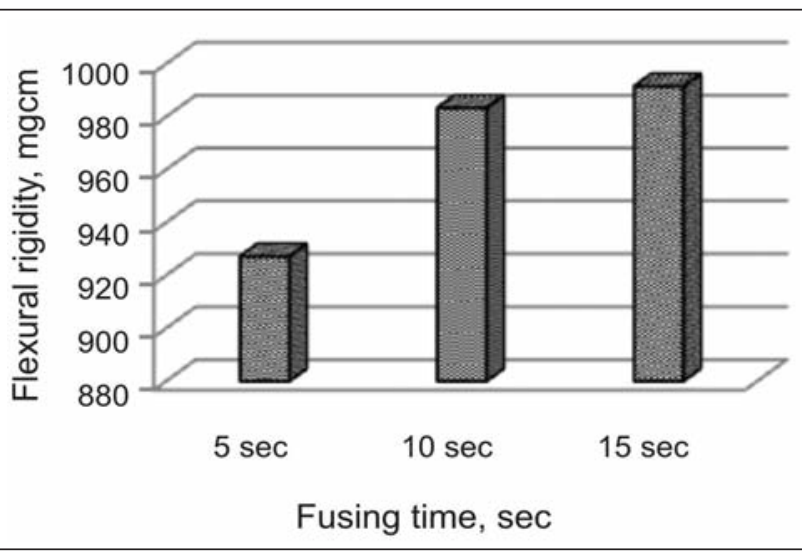

Fig. 4. Flexural rigidity of fabric with cotton plain fusible interlining at different fusing time at $160^{\circ} \mathrm{C}$

Generally available in very lightweights of $10 \mathrm{~g} / \mathrm{m}^{2}$ to $100 \mathrm{~g} / \mathrm{m}^{2}(12)$.

The highest bending length and flexural rigidity for nonwoven polyamide fusible interlinings was at $140^{\circ} \mathrm{C}$ fusing temperature as shown in figures $9-10$. The highest bending length and flexural rigidity for nonwoven polyamide fusible interlinings was at $10 \mathrm{sec}$ fusing time and $140^{\circ} \mathrm{C}$ fusing temperature as shown in figures $7-8$. 


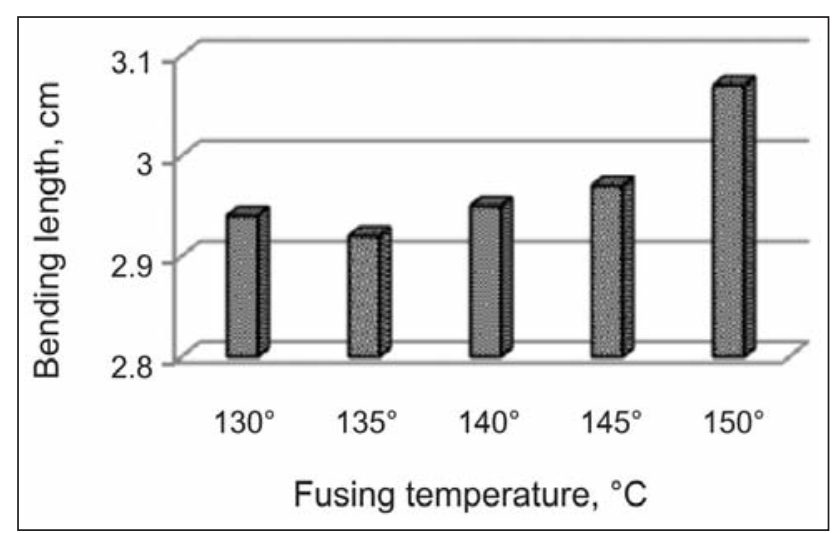

Fig. 5. Bending length of fabric with polyester twill $2 / 2$ fusible interlining at different fusing temperature

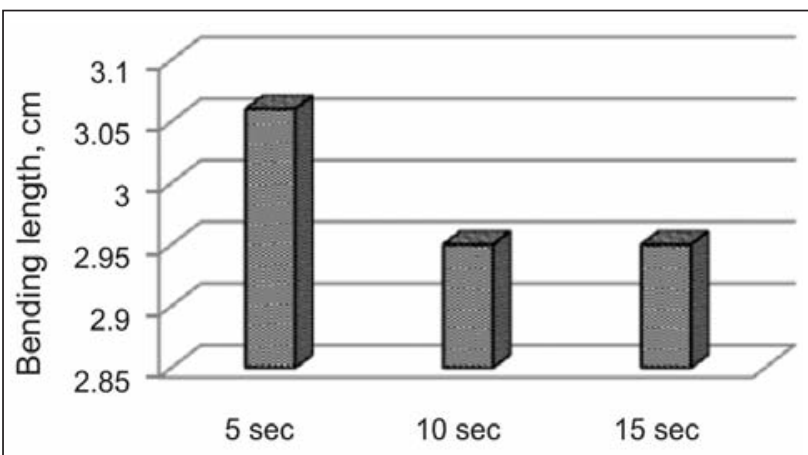

Fusing time, sec

Fig. 7. Bending length of fabric with polyester twill $2 / 2$ fusible interlining at different fusing time at $140^{\circ} \mathrm{C}$

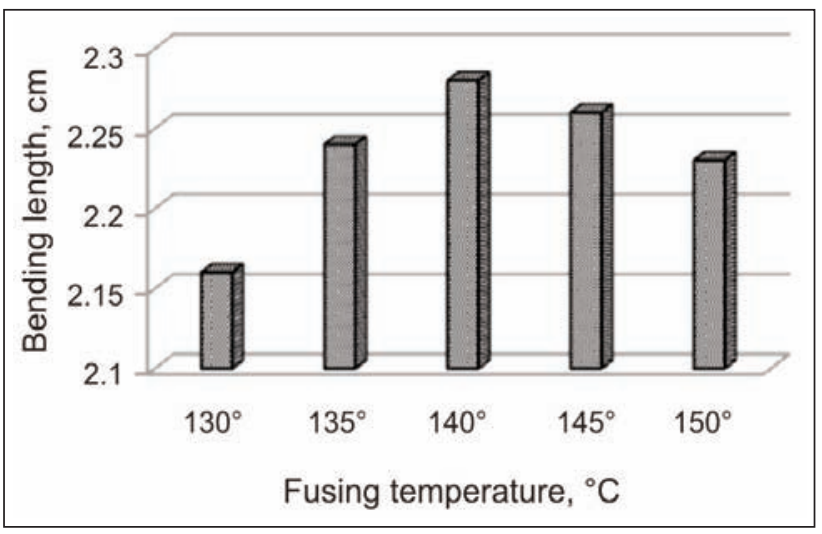

Fig. 9. Bending length of fabric with polyamide nonwoven fusible interlining at different fusing temperature

Interlinings type is also important for fused fabrics. Interlinings have different structural properties, different adhesives and different weave types. In this study three different interlinings were used. Bending length and flexural rigidity of cotton, polyester and polyamide nonwoven fusible interlining with cotton woven shirt fabric at $150^{\circ} \mathrm{C}$ and $10 \mathrm{sec}$ fusing time were shown in figures 13-14. Cotton fusible interlining with cotton fabric has the highest bending length and flexural rigidity as shown in figures 13-14. Nonwoven polyamide fusible interlining with cotton

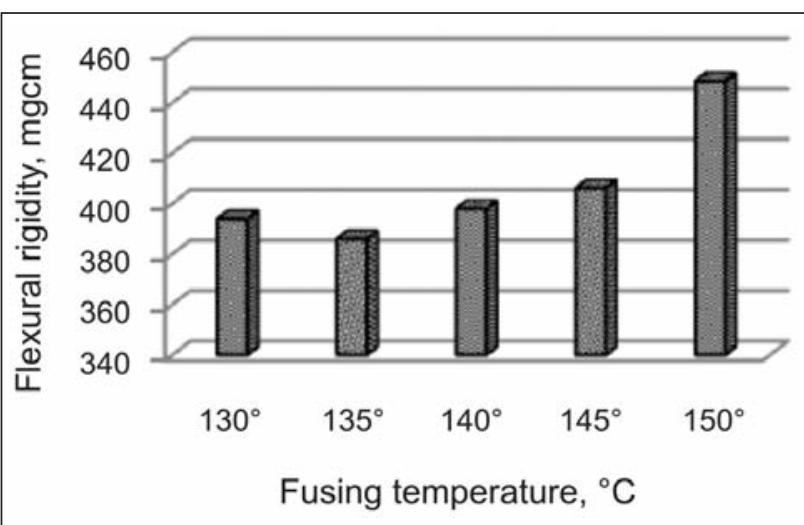

Fig. 6. Flexural rigidity of fabric with polyester twill $2 / 2$ fusible interlining at different fusing temperature

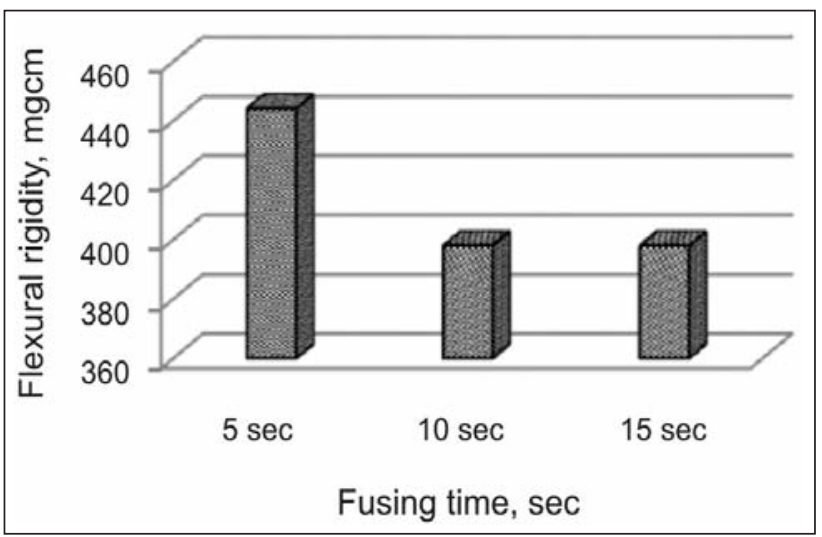

Fig. 8. Flexural rigidity of fabric with polyester twill $2 / 2$ fusible interlining at different fusing time at $140^{\circ} \mathrm{C}$

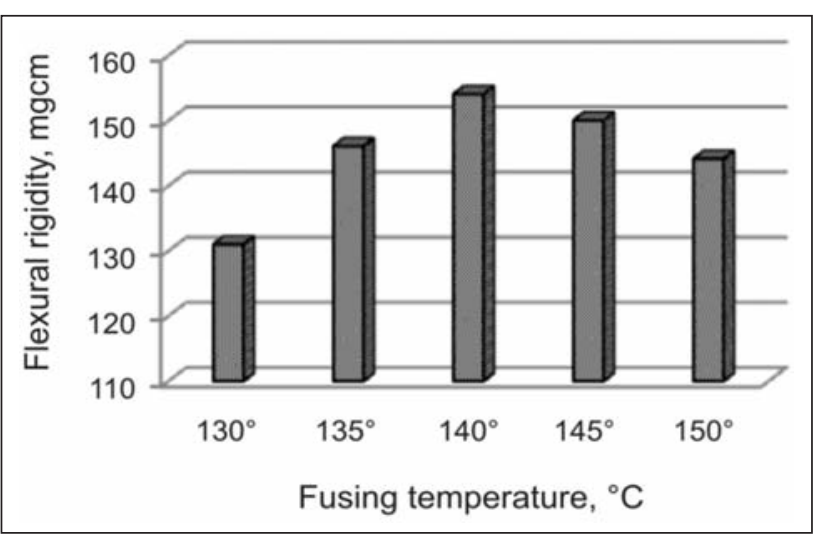

Fig. 10. Flexural rigidity of fabric with polyamide nonwoven fusible interlining at different fusing temperature

fabric has the lowest bending length and flexural rigidity as shown in figures $13-14$.

\section{The results of peel resistance}

The accuracy of the results of strength tests of adhesive bonds will depend on the conditions under which the bonding process is carried out. The main aim of this test is to analyze the mechanical stability of the adhesive layer between interlining and face fabric. During fusing, temperature, pressure and time of 


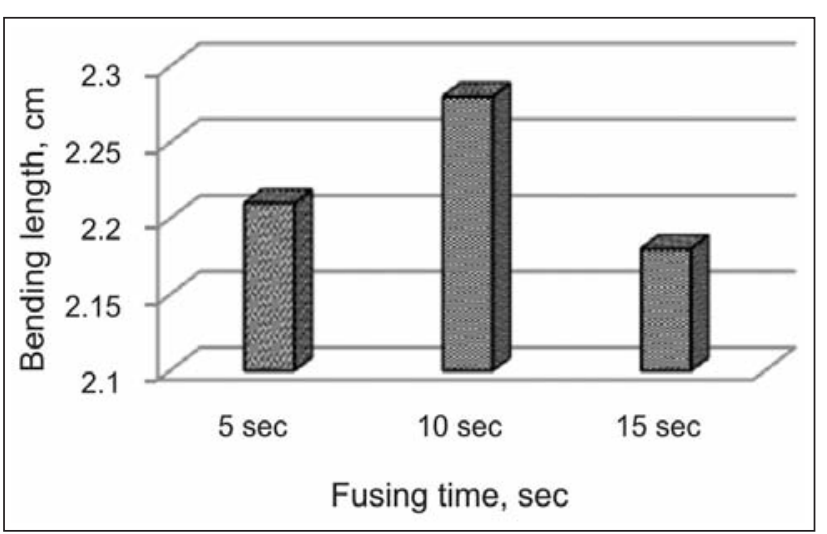

Fig. 11. Bending length of fabric with polyamide nonwoven fusible interlining at different fusing time at $140^{\circ} \mathrm{C}$

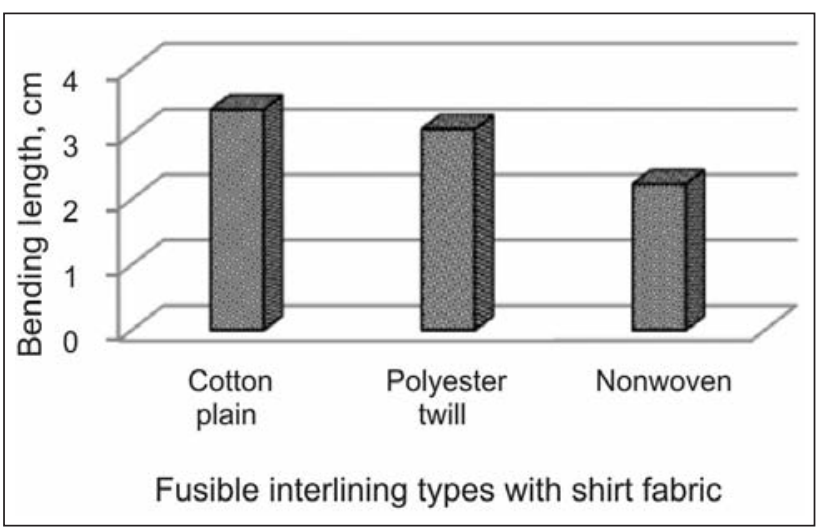

Fig. 13. Bending length of cotton, polyester and polyamide nonwoven fusible interlining with cotton fabric at $150^{\circ} \mathrm{C}$ and $10 \mathrm{sec}$ fusing time

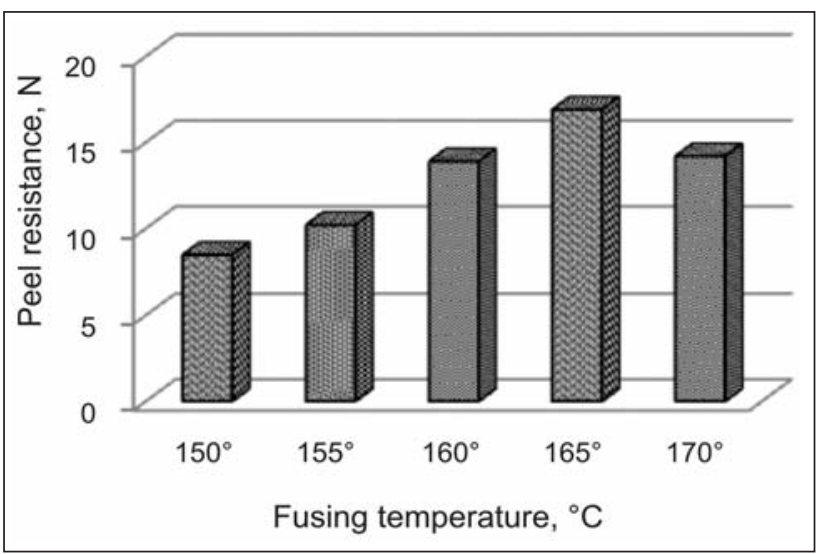

Fig. 15. Peel resistance results of fabric with cotton plain fusible interlining at different fusing temperature

operation are important factors determining the peel resistance.

The peel resistance test is primarily intended for determining the relative peel resistance between the fusible interlining and the fabric which is evaluated after fusing. The highest peel resistance for cotton fusible interlinings was $165^{\circ} \mathrm{C}$ fusing temperature as shown in figure 15.

The highest peel resistance between cotton fusible interlining and the cotton fabric was at $10 \mathrm{sec}$ fusing

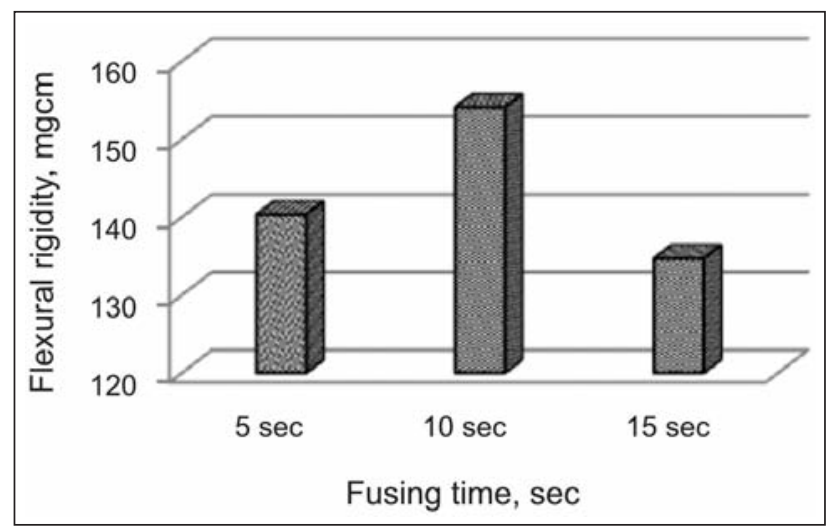

Fig. 12. Flexural rigidity of fabric with polyamide nonwoven fusible interlining at different fusing time at $140^{\circ} \mathrm{C}$

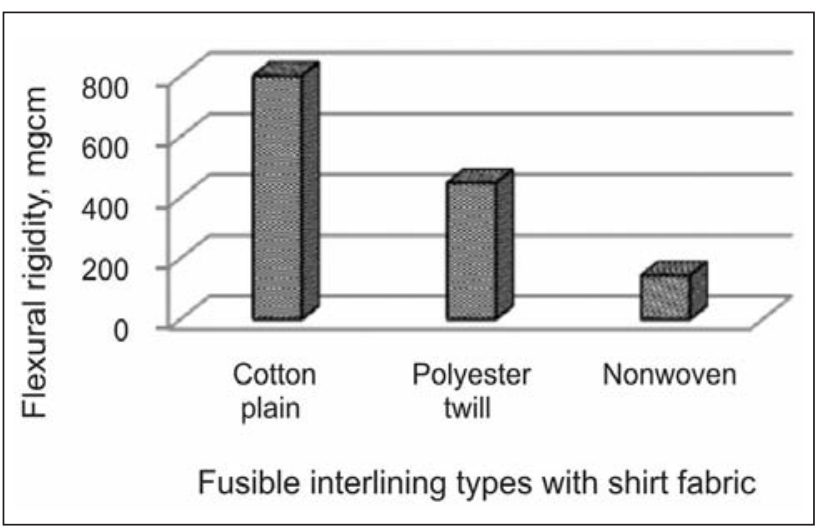

Fig. 14. Flexural rigidity of cotton, polyester and polyamide nonwoven fusible interlining with cotton fabric at $150^{\circ} \mathrm{C}$ and $10 \mathrm{sec}$ fusing time

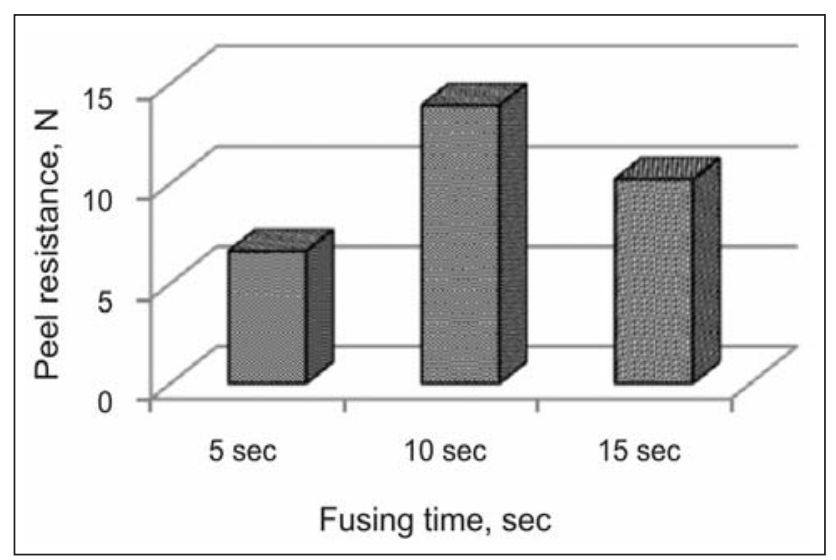

Fig. 16. Peel resistance results of fabric with cotton plain fusible interlining at different fusing time at $160^{\circ} \mathrm{C}$

time and $160^{\circ} \mathrm{C}$ fusing temperature as shown in figure 16.

Results indicated that the peel resistance between the polyester fusible interlining and cotton fabric increased with increase fusing temperature and fusing time.

The highest peel resistance for polyester fusible interlinings was at $150^{\circ} \mathrm{C}$ fusing temperature as shown in figure 17. Nonwoven interlining didn't peel from cotton shirt fabric at the peel resistance test. 


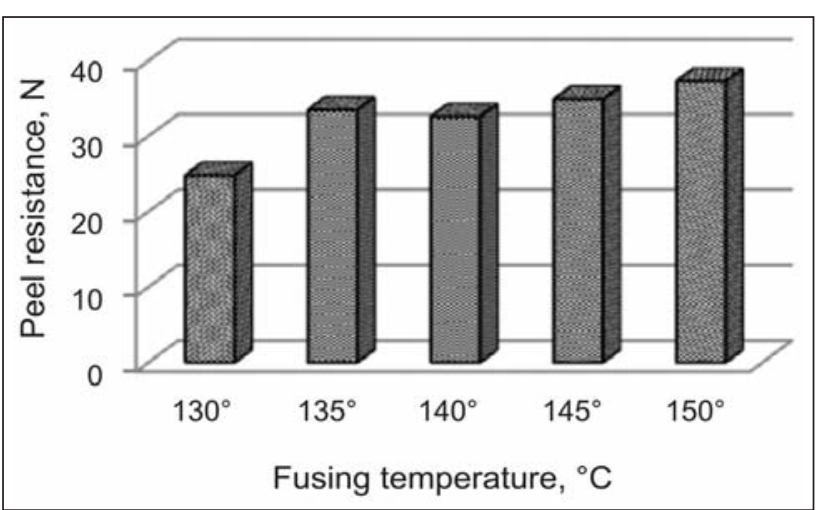

Fig. 17. Peel resistance results of fabric with polyester twill $2 / 2$ fusible interlining at different fusing temperature

The highest peel resistance for polyester fusible interlinings was at $10 \mathrm{sec}$ fusing time and $140^{\circ} \mathrm{C}$ fusing temperature as shown in figure 18.

Peel resistance between fusible polyester interlining and cotton fabric was higher than between fusible cotton interlining and cotton fabric at $150^{\circ} \mathrm{C}$ and $10 \mathrm{sec}$ fusing time is shown in figure 19. Fusible polyester interlining bonded to the cotton fabric stronger than fusible cotton interlining.

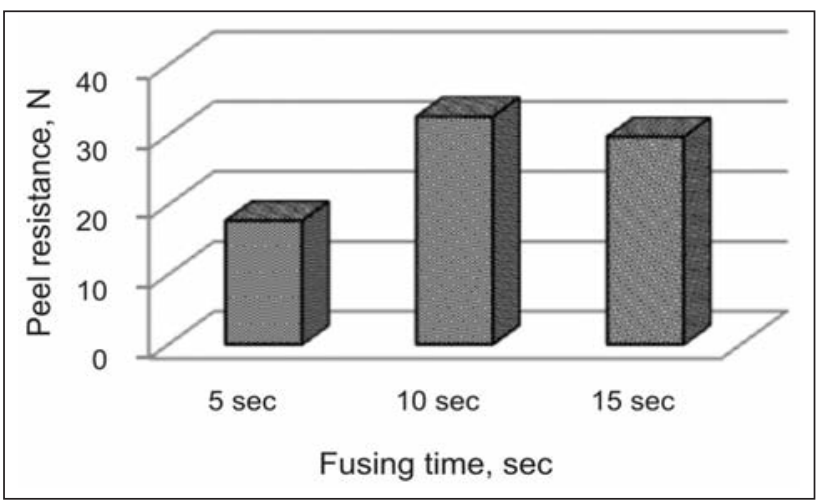

Fig. 18. Peel resistance results of fabric with polyester twill fusible interlining at different fusing time at $140^{\circ} \mathrm{C}$

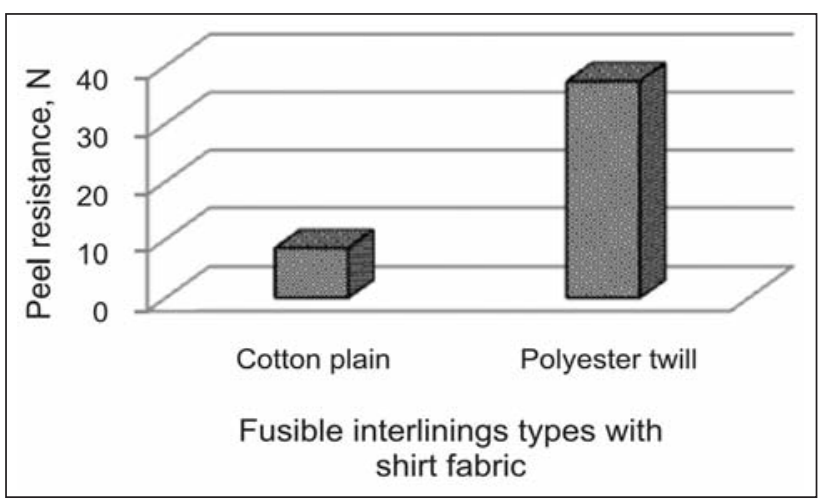

Fig. 19. Peel resistance results of cotton and polyester fusible interlinings with shirt fabric at $150^{\circ} \mathrm{C}$ and $10 \mathrm{sec}$ fusing time

\section{CONCLUSIONS}

The aim of this study to research the effects of different fusing temperature and fusing time on peel resistance and stiffness of woven fabric with fusible interlinings.

Cotton plain woven, polyester twill woven and polyamide nonwoven fusible interlinings were used with woven fabric. Peel resistance, bending length and flexural rigidity tests were done to the samples and results were analyzed.

Results indicated that the bending length and flexural rigidity of the fabric with cotton and polyester fusible interlining increased with increase fusing temperature. Results indicated that the stiffness of the fabric with polyamide nonwoven fusible interlining increased with increase fusing temperature until $140^{\circ} \mathrm{C}$ and increase fusing time until $10 \mathrm{sec}$. Low value of bending length means low stiffness and hence better drapability. However, a high value of bending length indicates high stiffness or poor drapability.

Interlining fusing time is also important for stiffness of fused fabric. The highest bending length and flexural rigidity for cotton fusible interlinings was at $15 \mathrm{sec}$ fusing time and $160^{\circ} \mathrm{C}$ fusing temperature. The highest bending length and flexural rigidity for polyester fusible interlinings was at 5 sec fusing time and $140^{\circ} \mathrm{C}$ fusing temperature.

The highest bending length and flexural rigidity for nonwoven polyamide fusible interlinings was at $140^{\circ} \mathrm{C}$ fusing temperature. The highest bending length and flexural rigidity for nonwoven polyamide fusible interlinings was at $10 \mathrm{sec}$ fusing time and $140^{\circ} \mathrm{C}$ fusing temperature.

Cotton fusible interlining with face fabric has the highest bending length and flexural rigidity. Nonwoven polyamide fusible interlining with cotton fabric has the lowest bending length and flexural rigidity.

Results indicated that the peel resistance between the cotton and polyester fusible interlining and fabric increased with increase fusing temperature and fusing time. The highest peel resistance for cotton fusible interlinings was at $165^{\circ} \mathrm{C}$ fusing temperature. The highest peel resistance between cotton fusible interlining and the face fabric was at $10 \mathrm{sec}$ fusing time at $160^{\circ} \mathrm{C}$ fusing temperature.

The highest peel resistance for polyester fusible interlinings was at $150^{\circ} \mathrm{C}$ fusing temperature. The highest peel resistance for polyester fusible interlinings was at $10 \mathrm{sec}$ fusing time at $140^{\circ} \mathrm{C}$ fusing temperature.

Peel resistance between fusible polyester interlining and face fabric was higher than between fusible cotton interlining and cotton fabric at $150^{\circ} \mathrm{C}$ and $10 \mathrm{sec}$ fusing time.

Dwell time, roller pressure, fuse line temperature, peel resistance, surface appearance and dimensional change must be check before starting bulk in the interlining fusing press machine.

A perfect working fusing press and appropriate fusing temperature and fusing time are needed to achieve good results for fusing interlining on the face fabric.

\section{ACKNOWLEDGEMENT}

Authors thank to Permess Interlining Inc.-Istanbul and Savcan Textile Bursa-Turkey for their helps during this study. 


\title{
BIBLIOGRAPHY
}

[1] Jeong S.H., Kim J.H., Hong C.J. Selecting optimal interlinings with a neural network, In: Textile Research Journal, 2000, vol. 70, no.11, pp. 1005-1010.

[2] Kim K.O., Sonehara S., Takatera M. Quantifying the appearance of jackets with adhesive interlinings, In: International Journal of Clothing Science and Technology, 2016, vol. 28, no.1, pp. 18-35.

[3] Alam, F. What is interlining? Different types, functions, uses, advantage and disadvantage of interlinings, available at: www.textilelearner.blogspot.com.tr/2013/12/ (accessed 12 February 2018).

[4] Phebe K., Krishnaraj K., Chandrasekaran B. Evaluating performance characteristics of different fusible interlinings, In: Indian Journal of Fibre \& Textile Research, 2014,vol.19, pp. 380-385.

[5] Amar Z., Al-Gamal G. Effect of different types and orientation of fusible interlinings on men striped shirt cuffs, In: Journal of American Science, 2015, vol. 11, no. 3, pp. 66-72.

[6] Yıldız E.Z., Özdil N. Subjective and objective evaluation of the handle properties of shirt fabric fused with different woven interlinings, In: Textile and Clothing, 2014, vol. 24, no.1, pp. 47-55.

[7] Qian Z., Cheekooi C., Wai K.C. The coefficient analysis between interlining physical properties and low-stress mechanical properties in terms of fusible interlinings and woollen fabric bonded interlinings, In: International Journal of Advances in Science and Technology, 2016, vol. 4, no. 4, pp. 20-23.

[8] Yükselkaya M.E., Howard T., Adanur S. Influence of the fabric properties on fabric Stiffness for the industrial fabrics, In: Textile and Clothing, 2008, vol. 18, no. 4, pp. 263-267.

[9] Sakthivel S., Ramachandran T., Chandhanu R., Padmapriya J., Vadivel P., Vignesh R. Nonwoven interlinings in apparel, In: The Indian Textile Journal, 2011.

[10] ASTM D 1338-64, Standard test methods for stiffness of fabrics, In: Annual Book of ASTM Standards, 1975, USA.

[11] ASTM D 1876-08, Standard test method for peel resistance of adhesives (T-Peel test), In: Annual Book of ASTM Standards, 2015, USA.

[12] BS EN ISO 13934-1, Textiles-tensile properties of fabrics - Part 1: Determination of maximum force and elongation at maximum force using strip method, 1999, British Standard.

\section{Authors:}

\section{AYCA GURARDA \\ MEHMET KANIK \\ NAIME CALISKAN}

Uludag University, Faculty of Engineering, Textile Engineering Department, Gorukle, Bursa, Turkey e-mail: aycagur@uludag.edu.tr; mekanik@uludag.edu.tr; naime190505@gmail.com

\section{Corresponding author:}

\author{
AYCA GURARDA
}

e-mail: aycagur@uludag.edu.tr 